\title{
TWO MONTHS IN THE CONGO
}

\author{
E. M. Poulton, B.A.(Oxon.), D.M., M.R.C.P., D.C.H., D.P.H. \\ Maternity and Child Health Adviser, WHO
}

IT was during the Christmas-New Year holiday period that the first rumour reached me at my home in Nigeria that I might have to go to the Congo. It was on January 4 that I received a telephone message instructing me to proceed there with the utmost urgency. So I left next morning and at 8 a.m. on January $7 \mathrm{I}$ arrived at Bakwanga in South Kasai, in a cargo aircraft loaded with salt fish.

It appeared that the urgent need was for famine relief. After the Congo achieved independence tribal minorities all over the country were compelled, by the pressure of unfriendly neighbours, to return to their own tribal areas. Thus the Baluba tribal homeland, with an indigenous population of 800,000 , had received some 400,000 refugees. The food supplies had been exhausted and no food could be obtained from the surrounding unfriendly areas. On top of this there was in September 1960 an incursion of regular Congolese troops into the area, and in the resultant fighting many crops were laid waste and shops looted and destroyed, and many civilians were killed.

In December 1960 the United Nations began a major operation by organizing an airlift of food to Bakwanga, the Baluba capital. They also supplied lorries to distribute that food throughout the countryside, and petrol, oil and maintenance facilities to operate them. The food supplied was maize flour, beans, fish (dried, salted or in tins), rice and skimmed milk powder.

Such was the success of this most costly operation that, whereas in early January the countryside was full of children desperately ill from kwashiorkor or simple starvation, when I left the area at the end of February even the mildest cases of cedema of the feet were hard to find outside the hospitals and feeding centres.

My first task was to supervise a camp for the families of sick refugee children which was organized near Bakwanga by the local branch of the Congolese Red Cross. I also assumed medical charge of the 70-bed children's section of the neighbouring hospital. The number of children and their mothers in these two establishments rose steadily until it became stable at about 600 people.

The camp was undoubtedly a success. It was run by Red Cross juniors, young teenage boys who would have been at secondary schools had any been still open. The food was cooked centrally. on a single electric stove with four plates and a wood fire outside when required. Two good wellbalanced cooked meals were given daily and each child received a mug of reconstituted dried milk (whole or skimmed) three times a day. The inmates of the camp consisted chiefly of familiesseveral children with their mother-of whom one member at least was severely ill with malnutrition. These children showed a slow but steady improvement and many families were discharged, or left the camp of their own accord to return home during the four weeks during which I was concerned with the camp.

The only therapy attempted in the camp was for infective diarrhœa, which was widespread, with sulphonamides, for respiratory infections (for which sulphonamides were available should the chest become involved) and for malarial fever, for which nivaquine was available. Other diseases were referred to the hospital and the frequent sores found in severe cases of kwashiorkor were treated at a nearby dispensary. All the camp inmates were vaccinated against smallpox.

Matters were less satisfactory in the children's department of the hospital next door. In the first place many of those admitted were in the last stages of kwashiorkor, either with gross œdema of all areas or with œdema of the dependent parts and dehydration of the remainder, and usually with a severe superadded infective enteritis. The death roll was consequently very heavy.

In addition, the hospital arrangements were not conducive to satisfactory treatment. There was, for example, no continuous nursing care. The nursing staff, who were certificated male nurses, were on duty from 6.30 a.m. to 3 p.m. (or 12 noon on Saturdays). During the intervening periods there was only one ' nurse guard' on duty for the whole hospital of 400 beds. He was located in reception. Furthermore, should the doctor wish to visit the hospital during these hours, he would find that his own consulting room and every room and cupboard except the wards themselves were locked, the nurses responsible having taken the keys away with them. In these conditions, therefore, in which the patients were dependent for all attention on their mothers or other relatives, proper treatment was impossible, despite the $\mathrm{X}$-ray department, laboratory, pharmacy and kitchen; 
which so favourably impressed visitors to the hospital.

The children's section of 70 beds accommodated up to 70 families, one family per bed. The beds had no linen; just a metal bedstead with a spongerubber mattress. On this bed the mother slept with all her children clustered round her, just as she would at home. This arrangement was quite satisfactory, considering the climate, and allowed the mattress to be washed over with disinfectant each morning at the same time as the floors. Also it was the only kind of arrangement that the patients would tolerate.

In consequence, ward nursing procedures were impossible. During the daytime every patient who was not too ill to be carried by his mother was outside in the compound or on the grass lawn. There was, therefore, a side-ward called the transfusion room, with two cubicles and three couches, where intravenous and subcutaneous therapy was carried out. This ward had two oxygen boxes for babies. Another side-ward was fully occupied by a very large (even for an adult) iron lung, which I once used to try and warm a shocked patient up, since it contained many electric light bulbs. There was, however, no sterilizer in the department, all sterilizing ordered being carried out next day in the autoclave belonging to the operating theatre. There was also no bath in the department, recourse being made to a tap in the compound.

Smallpox was a continual scourge in the hospital. There was an isolation block, but the isolation was never satisfactory, as the relatives, and sometimes the patients, wandered in and out. Officially all the hospital patients were vaccinated on admission, but enquiry showed that many were missed. Besides, the patients were outnumbered by their relatives, a fluctuating population who stayed with them in the hospital. I made an attempt to get all the inmates of the pædiatric section vaccinated, but even so there were still many without vaccination scars. In fact, during the four weeks in which I was concerned with the hospital four children developed smallpox while being treated in the general hospital for other conditions: one was admitted while in the incubation period and one patient developed smallpox while being isolated for measles. The trouble was that smallpox was regarded by the general population, nurses and patients alike, rather as measles is regarded in Britain - as a disease that goes round and everyone gets it sooner or later!

After spending four weeks in Bakwanga I was able to hand over the care of the children's section of the hospital and of the Red Cross camp to the Austrian medical team, consisting of six doctors, one dentist and some ancillary personnel. I then took responsibility for a sector of the countryside, comprising the most dense population of refugees This section had 15 rural dispensaries and two small emergency hospitals, i.e. dispensaries with some floor accommodation for the sick to sleep of.

I arranged regular daily tours, so that each dis pensary was visited at least once a week, and each of the emergency ' hospitals' at least twice, and each week on the same day. I took out supplies drugs to the dispensaries and saw any sick referre to me. I enquired about the deliveries of foos for each dispensary was also a feeding centre fô the malnourished children of the area, and I too back a small number of seriously ill patients to hospitals, as many as could be crammed into thie Willys station wagon. Every day I was stopped several times on the road because of people sick home and all of these I attended.

This work posed a number of practical medic problems: an older child lying at the side of th road in diabetic coma; a woman in labour sitting on the ground in the middle of a village and undergoing malarial rigors; and starving childre living too far from the nearest food distribution point. For the latter a large gift consignment of tinned baby foods was most useful-one tin be taken per child per day.

Regarding the kwashiorkor, which was the chie disease encountered among the children, the clinical picture was affected by the acute onseg Instead of the classical story of a child on a low-protein diet ever since it stopped breast feecto ing, we had children who had been relatively we nourished until the supply of protein was abrupt cut off a few weeks or months previously. I the resulting disease picture œdema of the legs was rapidly followed by ascites. The œdema the spread upward. Skin changes occurred subs sequent to the œdema and were therefore relatively late manifestation. Hair changes could be either early or late, but in any case were ne्f uncommon among the indigenous population.

The age distribution of kwashiorkor was also unusual. Since the babies were often partially breast fed to about three, four or five years (thoug Baluba mothers do not know the age of their children) the peak incidence was in the five to ro years group. But typical cases were seen in youn adults, and also in the old, who exhibited odeme. of the legs and ascites.

\section{Conclusion}

A local concentration of refugees in the regiofn of Bakwanga, South Kasai, led to an outbreak of kwashiorkor in an acute form among both childre and adults. A food relief programme by the United Nations authorities, assisted by the specialized agencies, was successful in terminating the outbreak in three months. 